\title{
Circular Economy - Key for the Change of Natural Resource from Scarce to Abundance
}

\author{
G. Jeyanthan, G. Ilankumaran
}

\begin{abstract}
As per world economic forum and UN's world population prospects, every year, the world's population is getting increased by 83 million more people, with this increasing population the usage of some of the available abundant natural resource has increased which may lead to scarcity of these resources. The world was using a traditional economic model based on a 'take-make-consume-throw away' approach of resources, it relays on cheap and easily available resources and starts producing goods, uses it and finally destroys it or dump it as a huge waste. So the world has to shift the gear to circular and sharing economy models. On a small scale, many companies are already working on the problems of resource usage efficiency by developing new technologies, such as those underlying the so-called sharing economy. Car sharing, and bike sharing for example. The circular economy is the process of not buying the goods but using the services and performance of the goods than owning it. This is the model where the manufacturers or the retailers are the owners of the goods and products used by us. The maintenance and repairs will be handled by the manufacturer which is also a part of the deal. In the recent years, the circular economy has gained a greater momentum in all parts of the world like corporate, governments, non-profit organizations and industry associations. The Circular economy will act as an innovative national level developmental strategy with a long-term vision for the future of a well-sustained world by increasing the abundance of the available natural resources. Yet the circular economy has a setback in its model; it also needs certain resource and energy for the process of recycling which is comparatively less. The major question will be whether the energy required for recycling is always lower than reproducing the product itself.
\end{abstract}

\section{INTRODUCTION}

As per world economic forum and UN's world population prospects, every year, the world's population is getting increased by 83 million more people, at this rate the world population will reach close to 10 million people at the end of the year 2050 compared to the current population of 7.6 billion people with India having 1.3 billion people in the country. With this increasing population, the usage of some of the available abundant natural resource has increased which may lead to scarcity of these resources. The natural resource plays a very important part in the economic growth and welfare of a country by the way of contribution to

Revised Manuscript Received on July 22, 2019.

G. Jeyanthan, Research Scholar (Part Time), Alagappa Institute of Management), Alagappa University, Karaikudi, jeyanthganesan@gmail.com,

G. Ilankumaran, Assistant Professor, Alagappa Institute of Management, Alagappa University, Karaikudi, ilankumarang@alagappauniversity.ac.in manufacturing sector, technological advancement, trade (both local and international), employment, better standards of living with a positive effect on the social, political and, importantly, the financial sector of the country. The world needs a paradigm shift from current methodology of consumption to a new methodology in order to maintain the available natural resource and increase the depleted resource.

According to the statistics released by the Organization for Economic Co-operation and Development, the world middle-class population will get doubled by the end of the year 2030, which leads to even greater consumption, because we consume more when we earn more. It clearly indicates that with the increase in population everyone cannot enjoy a high quality of life as they do now without changing the way we are doing now by the implementation of the circular and sharing economy.

\section{WORK METHODOLOGY}

The researcher has used the method of Analytical Research for supporting the paper. In Analytical Research the researcher has used the facts or Information already available by reviewing more than 100 articles from internet and magazines related to the research and analyzes to make a critical evaluation of the available resource. It also helped the researcher in finding out new Ideas relating to the topic being dealt. The researcher has also used a Qualitative method of interviewing some of the officials in the manufacturing sectors, consumers, social activists, businessman and also economic consultants. The collected data is collated and used in the research.

\section{LINEAR ECONOMY}

It is the traditional economic model based on a 'take-make-consume-throw away' approach of resources, it relays on cheap and easily available resources and starts producing goods, use it and finally destroy it or dump it as a huge waste. This type of economy creates a gradual demand for the available abundant natural resource by draining it slowly. China has the world's leading plastic recycling plant and recycles almost half of the world's exports of waste paper, metals and used plastics till 2017, now China has banned the imports of 24 kinds of solid waste. So the plastics started piling up in western countries and the United States and this may be a huge problem for the countries. This condition will allow a huge landfill, which is

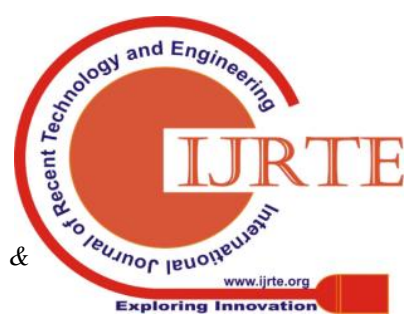


the final stage of the resources life cycle.

The linear economy

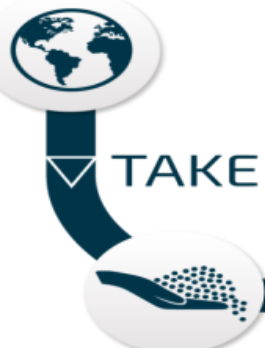

Materials

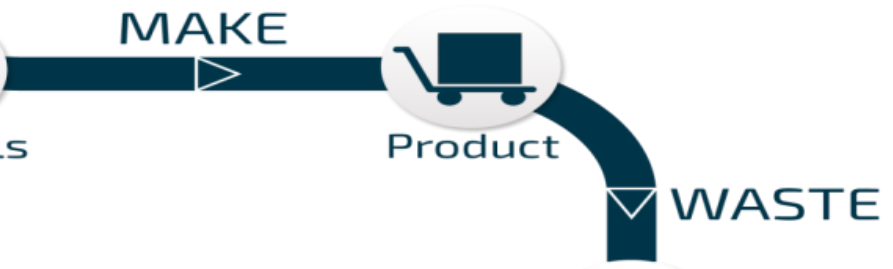

而

\section{End of life}

\section{Demerits of Linear Economy}

It is clearly seen that linear economy is not an acceptable model for the future. The major disadvantages of this model are no solutions for the reducing shortage of the available raw materials, increasing pollution, increasing material demand and the increasing demand for the responsible products like oil, minerals and other natural resources. The negatives are price volatility (ie) fluctuation in the commodity prices is an upper hand since the year 2006. It not only causes the problem for the buyers of raw materials but also results in long-term increases in the prices of raw materials.

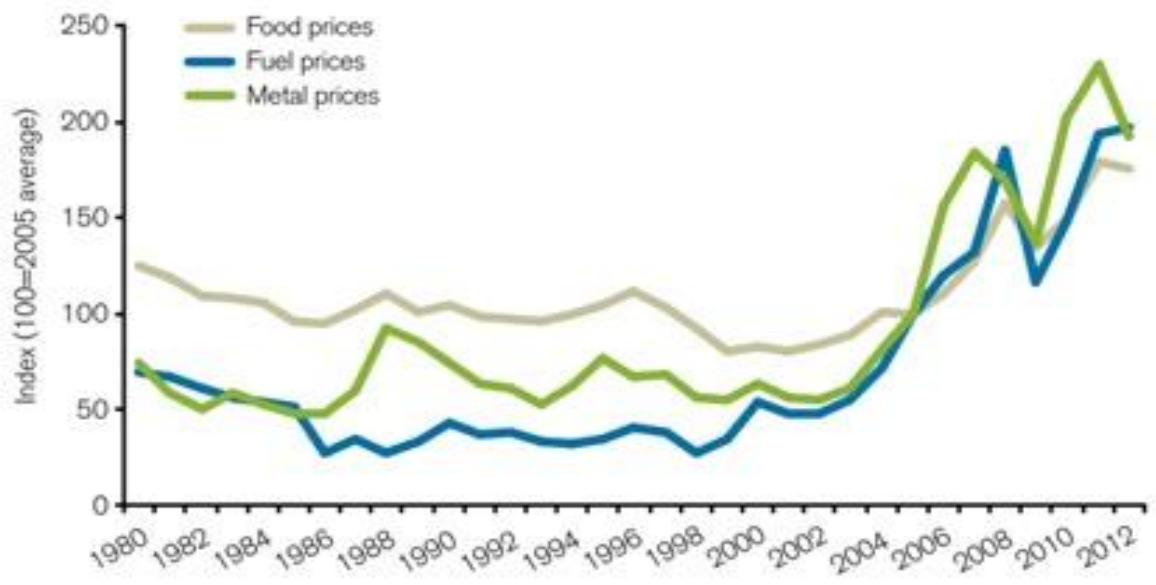

Source: Chatham House based on IMF (2012).

\section{Other negatives are}

- Increase in material demand

- Degradation of the World's Eco system

- Decreasing lifetime of the products

- Misfit with the need for the accountability of the products

\section{SHARING ECONOMY}

On a small scale, many companies are already working on the problems of resource usage efficiency by developing new technologies, such as those underlying the so-called sharing economy. Car sharing, and bike sharing, for example, may reduce the number of vehicles on the road and also it limits their growth in manufacturing many numbers, while house and residence sharing provides a smart way of using our residences more efficiently, by making use of the assets in a more resourceful way. This type of economy reduces the environmental impact of our actions and also generates new revenue streams for the people.As per the researcher the sharing economy is peer to peer exchange of goods and services either by sharing or acquiring which will reduce the wastage of usable resources. In the current scenario of urbanization it is done by using online platforms like car sharing app to share the service and OLX is used to sell the used goods. 


\section{CIRCULAR ECONOMY}

The concept of a circular economy (CE) was raised to the world by two British environmental economists David W. Pearce and R. Kerry Turner in 1989. It is the process of not buying the goods, but using the services and performance of the goods than owning it. This is the model where the manufacturers or the retailers are the owners of the goods and products used by us. The maintenance and repairs will be handled by the manufacturer which is also a part of the deal made between the consumers and the manufacturers. The definition of the circular economy as per Ellen MacArthur "an economic and industrial system that takes the reusability of products and raw materials and the resilience of natural resources as a starting point, minimizes the destruction of value throughout the entire system and strives for the creation of value in each link of the system". It can be simply explained as trading the products and services in a closed loop which is regenerative in design. As mentioned earlier the maintenance and repair works are carried out by the manufacturer or the owner of the goods and it is regenerated or redesigned as per the latest advancement of technology whenever needed. The circular economy model can be given in 3 steps

- Producing the goods by manufacturer

- Using the goods by consumers

- Returning the goods to the manufacturer

The circular economy mainly stands on the process of waste management and converting the country with environmental benefits along with economic benefits.

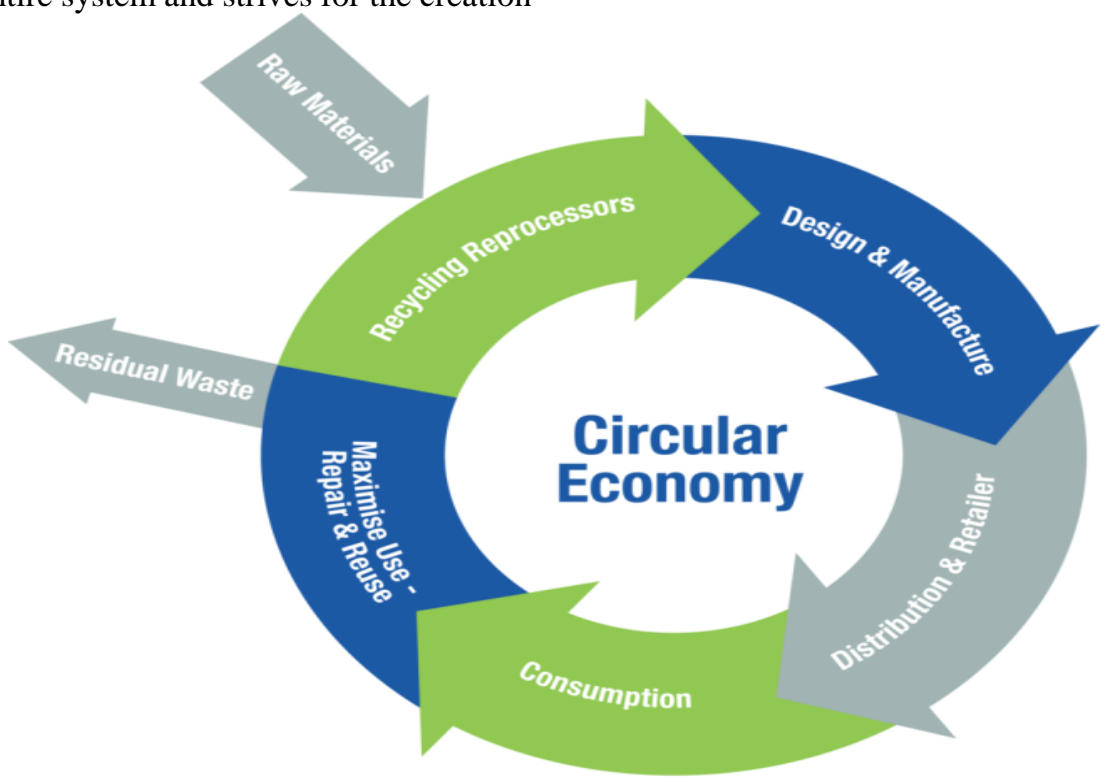

\subsection{Benefits of Circular Economy}

The concept of Circular economy is 3R Reducing, Reusing, and Recycling. The benefit of the circular economy is creating a closed loop of the goods used by the consumer, which aims to reuse the waste indefinitely and make a new product without changing the nature and properties of the original material. The circular economy's goal will be to decouple the economic growth by allowing prosperity to continue rising and reducing the consumption of natural resources like oil, minerals and other depleting resources. The focal point of the circular economy includes reducing the consumption of raw materials, designing eco-friendly products, increasing the lifespan of products by the process of maintenance and repair, and converting waste flows into raw materials.

\subsection{Implementation of Circular Economy}

In the recent years, the circular economy has gained a greater momentum in all parts of the world like corporate, governments, non-profit organizations and industry associations. Everyone has been trying to understand the procedure of circular economy. The action plan of implementing the circular economy is to improve global competitiveness, opening the way to new business opportunities, and generate new jobs. The world has already started implementing the circular economy, In January 2017

the European Commission reported on the delivery and progress of key initiatives of its 2015 Action Plan in the Report on the implementation of the Circular Economy Action Plan and annex. The EU has planned to invest more than 100 million in about 80 circular economy projects.

The fundamental idea behind introducing Circular economy is to reduce the demand of raw materials of all types in the world. The Table below shows the relationship between GDP by sector and main material categories' consumption after implementing the circular economy in one of the European Unions.

\begin{tabular}{|l|l|l|l|l|l|l|}
\hline $\begin{array}{l}\text { Indica } \\
\text { tors }\end{array}$ & $\begin{array}{l}\text { Domes } \\
\text { tic } \\
\text { Materi } \\
\text { al } \\
\text { Consu } \\
\text { mption }\end{array}$ & $\begin{array}{l}\text { Fos } \\
\text { sil } \\
\text { Fue } \\
\text { ls }\end{array}$ & $\begin{array}{l}\text { M } \\
\text { et } \\
\text { al } \\
\text { s }\end{array}$ & $\begin{array}{l}\text { Non } \\
\text {-Met } \\
\text { allic } \\
\text { Min } \\
\text { erals }\end{array}$ & $\begin{array}{l}\text { Bio } \\
\text { mas } \\
\text { s }\end{array}$ & $\begin{array}{l}\text { Che } \\
\text { mical } \\
\text { s and } \\
\text { Fertil } \\
\text { izers }\end{array}$ \\
\hline GDP & 0.69 & 0.14 & -0. & 0.82 & 0.55 & 0.62 \\
\hline $\begin{array}{l}\text { INDU } \\
\text { STRY }\end{array}$ & 0.74 & 0.02 & -0. & 0.85 & 0.57 & 0.77 \\
\hline $\begin{array}{l}\text { SERV } \\
\text { ICE }\end{array}$ & 0.63 & 0.23 & -0. & 0.87 & 0.49 & 0.53 \\
\hline
\end{tabular}

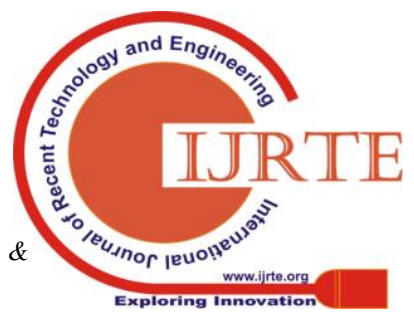


It clearly shows that consumption of all the raw materials has been reduced after the transformation to circular economy.

The European Union adapted circular economy package in the year 2018, with a target of recycling all plastic packaging by the year 2030. The European Commission and the European Economic and Social Committee has planned to host circular economy stakeholder conference on 6 and 7 March 2019 for facilitating policies on implementation by the stakeholders Also the European Union has planned to increase the recycling target at different phases, the table below shows the different categories of the packaging framed by them But the means are yet to be decided by the union to reach the set target.

\begin{tabular}{|l|l|l|}
\hline Packaging type & 2025 target & 2030 target \\
\hline Plastics & $55 \%$ & $55 \%$ \\
\hline Wood & $60 \%$ & $75 \%$ \\
\hline Ferrous metal & $75 \%$ & $85 \%$ \\
\hline Aluminum & $75 \%$ & $85 \%$ \\
\hline Glass & $75 \%$ & $85 \%$ \\
\hline Paper and cardboard & $75 \%$ & $85 \%$ \\
\hline
\end{tabular}

\subsection{Huddles in implementing of Circular Economy}

The challenges of implementing the circular lie with both types of counties either new to this model or already going with the model, the implementation difficulties differ in range according to their expertise level in the model and the level of transition to the circular economy. It also depends on the political structure, region, and governance of the country. Even the western countries like Germany, Belgium, and Ireland have federal level issues in the implementation of the circular economy. Some other major challenges are education, consumer awareness, behavior, and knowledge. A well thought out design and governance strategy are required for the desired transition to the circular economy.

\section{REVIEW QUESTIONS}

6.1. What is a sharing economy as per the research? As per the researcher the sharing economy is peer to peer exchange of goods and services either by sharing or acquiring which will reduce the wastage of usable resources. In the current scenario of urbanization it is done by using online platforms like car sharing app to share the service and OLX is used to sell the used goods.

6.2. Briefly explain what is a circular economy? It can be simply explained as trading the products and services in a closed loop which is regenerative in design. As mentioned earlier the maintenance and repair works are carried out by the manufacturer or the owner of the goods and it is regenerated or redesigned as per the latest advancement of technology whenever needed. The circular economy model can be given in 3 steps

- Producing the goods by manufacturer

- Using the goods by consumers

- Returning the goods to the manufacturer
The circular economy mainly stands on the process of waste management and converting the country with environmental benefits along with economic benefits.

6.3. As per research what is the goal of a circular economy? The circular economy's goal will be to decouple the economic growth by allowing prosperity to continue rising and reducing the consumption of natural resources like oil, minerals and other depleting resources. The focal point of the circular economy includes reducing the consumption of raw materials, designing eco-friendly products, increasing the lifespan of products by the process of maintenance and repair, and converting waste flows into raw materials.

\subsection{What is the current status of implementation of the circular economy?}

The European Union adapted circular economy package in the year 2018, with a target of recycling all plastic packaging by the year 2030. The European Commission and the European Economic and Social Committee has planned to host circular economy stakeholder conference on 6 and 7 March 2019 for facilitating policies on implementation by the stakeholders Also the European Union has planned to increase the recycling target at different phases, the table below shows the different categories of the packaging framed by them

\begin{tabular}{|l|l|l|}
\hline Packaging type & 2025 target & 2030 target \\
\hline Plastics & $55 \%$ & $55 \%$ \\
\hline Wood & $60 \%$ & $75 \%$ \\
\hline Ferrous metal & $75 \%$ & $85 \%$ \\
\hline Aluminum & $75 \%$ & $85 \%$ \\
\hline Glass & $75 \%$ & $85 \%$ \\
\hline Paper and cardboard & $75 \%$ & $85 \%$ \\
\hline
\end{tabular}

But the means are yet to be decided by the union to reach the set target.

\subsection{What are the difficulties in implementing} Circulareconomy?

The challenges of implementing the circular lie with both types of counties either new to this model or already going with the model, the implementation difficulties differ in range according to their expertise level in the model and the level of transition to the circular economy. It also depends on the political structure, region, and governance of the country. Even the western countries like Germany, Belgium, and Ireland have federal level issues in the implementation of the circular economy. Some other major challenges are education, consumer awareness, behavior, and knowledge. A well thought out design and governance strategy is required for the desired transition to the circular economy. A key challenge will the implementation and integration of the new strategy into the existing policy and economy as the major existing arrangements are still designed for the linear economy.

\subsection{Brief on implications of the circular economy in the} consumption of natural resources? 
The fundamental idea behind introducing Circular economy is to reduce the demand of raw materials of all types in the world. The Table below shows the relationship between GDP by sector and main material categories' consumption after implementing the circular economy in one of the European Union till recent years.

\subsection{What is the traditional economic model of consumption?}

It is the traditional economic model based on a 'take-make-consume-throw away' approach of resources, it relays on cheap and easily available resources and starts producing goods, use it and finally destroy it or dump it as a

\begin{tabular}{|l|l|l|l|l|l|l|}
\hline Indicators & $\begin{array}{l}\text { Domestic } \\
\text { Material } \\
\text { Consumpti } \\
\text { on }\end{array}$ & $\begin{array}{l}\text { Foss } \\
\text { il } \\
\text { Fuel } \\
\text { s }\end{array}$ & $\begin{array}{l}\text { Meta } \\
\text { 1s }\end{array}$ & $\begin{array}{l}\text { Non-Metal } \\
\text { lic } \\
\text { Minerals }\end{array}$ & $\begin{array}{l}\text { Bioma } \\
\text { ss }\end{array}$ & $\begin{array}{l}\text { Chemica } \\
\text { ls and } \\
\text { Fertilize } \\
\text { rs }\end{array}$ \\
\hline GDP & 0.69 & 0.14 & -0.53 & 0.82 & 0.55 & 0.62 \\
\hline $\begin{array}{l}\text { INDUSTR } \\
\text { Y }\end{array}$ & 0.74 & 0.02 & -0.44 & 0.85 & 0.57 & 0.77 \\
\hline SERVICE & 0.63 & 0.23 & -0.56 & 0.87 & 0.49 & 0.53 \\
\hline
\end{tabular}

It clearly shows that consumption of all the raw materials has been reduced after the transformation to circular economy.

\subsection{What is the urgent need for saving the natural resources of the world?}

As per world economic forum and UN's world population prospects, every year, the world's population is getting increased by 83 million more people, at this rate the world population will reach close to 10 million people at the end of the year 2050 compared to the current population of 7.6 billion people with India having 1.3 billion people in the country. With this increasing population, the usage of some of the available abundant natural resource has increased which may lead to scarcity of these resources.

\subsection{State the reason for which we need a paradigm shift from the current methodology o consumption?} The natural resource plays a very important part in the economic growth and welfare of a country by the way of contribution to manufacturing sector, technological advancement, trade (both local and international), employment, better standards of living with a positive effect on the social, political and, importantly, the financial sector of the country. The world needs a paradigm shift from current methodology of consumption to a new methodology in order to maintain the available natural resource and increase the depleted resource.

\subsection{Briefly explain the methodology used in the research?} The researcher has used the method of Analytical Research for supporting the paper. In Analytical Research the researcher has used the facts or Information already available by reviewing more than 100 articles from internet and magazines related to the research and analyzes to make a critical evaluation of the available resource. It also helped the researcher in finding out new Ideas relating to the topic being dealt. The researcher has also used a Qualitative method of interviewing some of the officials in the manufacturing sectors, consumers, social activists, businessman and also economic consultants. The collected data is collated and used in the research.

huge waste. This type of economy creates a gradual demand for the available abundant natural resource by draining it slowly.

\subsection{What are the demerits of Linear Economy as per the} researcher?

It is clearly seen that linear economy is not an acceptable model for the future. The major disadvantages of this model are no solutions for the reducing shortage of the available raw materials, increasing pollution, increasing material demand and the increasing demand for the responsible products like oil, minerals and other natural resources. The negatives are price volatility (ie) fluctuation in the commodity prices is an upper hand since the year 2006. It not only causes the problem for the buyers of raw materials but also results in long-term increases in the prices of raw materials.

Other negatives are

- Increase in material demand

- Degradation of the World's Eco system

- Decreasing lifetime of the products

- Misfit with the need for the accountability of the products

\subsection{What according to the researcher are the remedial measures for the existing issue regarding the natural resource?}

As per the researcher our future prosperity will be in peril if we hesitate to take a paradigm shift from the existing traditional economy to the sharing and circular economy styles. Yet the circular economy has a setback in its model; it also needs certain resource and energy for the process of recycling which is comparatively less. The major question will be whether the energy required for recycling is always lower than reproducing the product itself.

\section{FUTURE OF THE CIRCULAR ECONOMY}

As per a review, the implementation of the circular economy will produce a clear future in the field of sustainable development and entrepreneurship. The research is also very much optimistic and prescriptive in nature. The Circular economy will act as an innovative national level developmental strategy with a long-term vision for the future of a well-sustained world by increasing the abundance of the available natural resources.

\section{CONCLUSION}

Environmental degradation is not only a single national problem but also it is the global problem. If this existing condition prevails it will erode our lifestyle and lead to danger. Overall our future prosperity will be in peril if we hesitate to take a paradigm shift

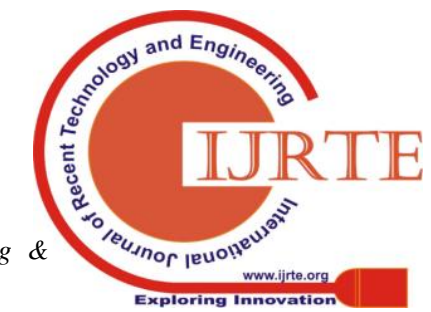


from the existing traditional economy to the sharing and circular economy styles. Yet the circular economy has a setback in its model; it also needs certain resource and energy for the process of recyclingwhich is comparatively less. The major question will be whether the energy required for recycling is always lower than reproducing the product itself.

\section{REFERENCES}

[1] world-population-you-might-not-know/

[2] http://eprints.1se.ac.uk/18905/1/Scarce\%20or\%20abundan $\mathrm{t}$ (1sero).pdf

[3] file:///C:/Users/ADMIN/Downloads/9783319677521-c2.p df

[4] https://link.springer.com/article/10.1023/A:10083894220 $\underline{19}$

[5]http://eprints.1se.ac.uk/cgi/stats/report/eprint

[6] https://www.youtube.com/watch? $\mathrm{v}=\mathrm{Cd}$ isKtGaf8

[7] http://www.economywatch.com/features/A-Linear-Econo mys-Environmental-and-Social-Consequences0911.html

[8]https://www.nytimes.com/2018/01/11/world/china-recycla bles-ban.html

[9] https://www.navigantresearch.com/blog/2018-a-year-for-a ction-and-implementation-for-circular-economy

[10] http://www.switchtogreen.eu/wordpress/wp-content/uplo ads/wp-post-to-pdf-enhanced-cache/1/circular-economystrategy.pdf

[11] http://entreprenorskapsforum.se/wp-content/uploads/201 5/12/CircularEconomy webb.pdf

[12] https://www.omicsonline.org/open-access/key-challenge s-for-transformations-towards-a-circular-economy--thest atus-quo-in-germany-2252-5211-1000262.php?aid=852 $\underline{97}$

[13] https://www.supplychainquarterly.com/news/20171019-t he-challenges-of-implementing-a-circular-economy/

[14] https://www.reedsmith.com/en/perspectives/2016/05/theimplications-of-the-transition-to-a-circular-e

[15]http://ec.europa.eu/environment/circular-economy/index _en.htm 